\section{Exposure to misoprostol and hormones during pregnancy and risk of congenital anomalies}

\author{
Exposição ao misoprostol e hormônios durante a \\ gravidez e risco de anomalia congênita
}

\author{
1 Faculdade de Farmácia, \\ Universidade Federal do Rio \\ Grande do Sul, Porto Alegre, \\ Brasil. \\ ${ }^{2}$ Hospital de Clínicas de \\ Porto Alegre, Universidade \\ Federal do Rio Grande do Sul, \\ Porto Alegre, Brasil. \\ 3 Programa de Pós- \\ Graduação em \\ Epidemiologia, Universidade \\ Federal do Rio Grande do Sul, \\ Porto Alegre, Brasil. \\ Correspondence \\ T. S. Dal Pizzol \\ Faculdade de Farmácia, \\ Universidade Federal do \\ Rio Grande do Sul. \\ Rua Vicente da Fontoura \\ 2035, apto. 602, \\ Porto Alegre, RS \\ 90640-003, Brasil. \\ tatiane.silva@ufrgs.br
}

\begin{abstract}
This study evaluated the association between use of misoprostol and other drugs to induce menstruation, and congenital anomalies. A sample of 4,856 pregnant women 20 years and older were enrolled consecutively in prenatal services in the Unified National Health System, in six Brazilian State capitals. Data on socio-demographics and use of medicines were obtained using an interview from the 21st to 28th week of pregnancy. Other data, including information on delivery and diagnosis of congenital anomalies by the attending neonatal physician were obtained from patient charts. Potential confounders were adjusted by logistic regression. Use of drugs to induce menstruation was reported by 707 women (14.6\%), of whom 120 (17\%) reported use of misoprostol. After adjusting for the study center, a positive association was observed between misoprostol and congenital anomalies (OR = 2.64; 95\%CI: 1.03-6.75); $a$ positive association was also observed for sex hormones $(O R=2.24$; 95\%CI: 1.06-4.74). The results suggest that the use of misoprostol or sex hormones during pregnancy increases the risk of congenital anomalies.
\end{abstract}

Misoprostol; Hormones; Abnormalities; Women's Health
Tatiane da Silva Dal Pizzol 1

Maria Teresa Vieira Sanseverino 2

Sotero Serrate Mengue 3

\section{Introduction}

Misoprostol is a synthetic prostaglandin E1 analogue (PGE1), originally approved for the prevention and treatment of gastric ulcer. Its effectiveness has been investigated in elective medical abortions, labor induction, uterine evacuation following fetal death, postpartum hemorrhage, and cervical maturation, particularly in countries where abortion is legal 1,2 .

In Brazil, misoprostol has become the most popular recourse for inducing abortion, although this practice is illegal, with only two exceptions: cases in which the pregnant woman's life is at risk, and pregnancies resulting from rape 3 . Use of misoprostol by women seeking treatment at emergency services due to incomplete abortions calls attention to the resulting maternal health risk. Besides misoprostol, drugs containing estrogens and progestagens have been associated with attempted abortions 4,5,6,7.

Maternal health risk is not the only problem associated with indiscriminate use of abortive substances. According to controlled clinical trials, medical abortions using misoprostol can lead to failed abortion in more than $10 \%$ of cases, requiring the use of a complementary abortive method 1 . The single use of misoprostol is significantly less effective than combinations with mifepristone, methotrexate, or tamoxifen, and is not recommended in cases of firsttrimester medical abortion 1,8. In conditions 
where illegal abortion is commonly performed, without adequate care and at inadequate doses, the use of misoprostol may fail to interrupt the pregnancy, thus generating anxiety concerning risk to the fetus ${ }^{9}$. Case reports and case-control studies suggest that the use of misoprostol in unsuccessful abortions can be associated with congenital anomalies, including cranial nerve defects 10 and Möebius sequence 11,12. A systematic review of four case-control studies on the adverse effects of misoprostol on pregnancy outcome showed that prenatal exposure to misoprostol increases the odds of Möebius sequence and terminal transverse limb defects, as compared to unexposed individuals 13. However, the association between misoprostol and other types of congenital anomalies was not adequately elucidated in this analysis, due to interstudy heterogeneity.

In this context, the objective of the current study is to evaluate the association between misoprostol and other widely used products for inducing menstruation, and congenital anomalies in fetuses and newborns. A letter with a preliminary analysis of the main findings presented in this article was published previously by the authors 14

\section{Methods}

The current study is a secondary analysis of the Brazilian Study on Gestational Diabetes, a multicenter cohort that investigated diabetes and glucose intolerance in pregnant women in relation to prevalence, risk factors, incidence of obstetric and neonatal complications, prognostic factors, and diagnostic criteria. The first phase of the study included the enrolment of pregnant women, interviews, anthropmetric measures, and a glucose tolerance test, when the women were in the $21^{\text {st }}$ to $28^{\text {th }}$ week of pregnancy. The second phase involved follow-up of the pregnancy through a patient chart review. The third phase consisted of information on delivery and the newborn.

The study analyzed the data on use of misoprostol and other products to induce menstruation during the gestational period, recorded during the first phase of the Brazilian Study on Gestational Diabetes. The sample consisted of women 20 years or older who were in the $21^{\text {st }}$ to $28^{\text {th }}$ week of pregnancy, and who consecutively sought care at prenatal services in health units under the Unified National Health System (SUS) located in Fortaleza (Ceará State), Manaus (Amazonas), Porto Alegre (Rio Grande do Sul), Rio de Janeiro (Rio de Janeiro), Salvador (Bahia), and São Paulo (São Paulo) from February 1991 to June 1995. The health services were chosen on the basis of demand by pregnant women treated there and feasibility in the implementation and follow-up of all phases in the Brazilian Study on Gestational Diabetes.

Inclusion criteria data were obtained from the woman's medical chart or prenatal card. For first appointments, the data could be obtained directly from the patient. Women with a history of diabetes mellitus prior to the pregnancy were excluded.

The interview was structured to answer questions related to socio-demographics, in addition smoking, alcohol, medication, and reproductive history. Variables related to the current pregnancy, delivery, and neonatal health conditions were collected from the mother's medical chart. The specific use of products to induce menstruation was investigated with the question: "To discover whether you were pregnant, did you use some kind of drug for your period to come?".

Data on diagnosis of congenital anomaly were collected from the mother's medical chart. Congenital anomalies were classified according to the 9th Revision of the International Classification of Diseases (ICD-9) 15. The composition of each of the products reported by the women was identified with the aid of the Catálogo Brasileiro de Especialidades Farmacêuticas, Dicionário de Especialidades Farmacêuticas, editions 1984 through 1995 16,17,18,19,20,21,22,23,24,25,26,27, and drug package inserts.

Data were stored using Epi Info version 6.04b (Centers for Disease Control and Prevention, Atlanta, USA) and analyzed with SPSS version 13.0 (SPPS Inc., Chicago, USA). A logistic regression model was used to estimate the odds ratios (OR) adjusted for potential confounders reported in the literature. The first phase of the model's construction examined various risk factors for the target outcome, testing socio-demographic factors (age, skin color, schooling, study center, marital status, and pre-gestational body mass index - BMI); reproductive history (previous abortion, planning of the index pregnancy, and parity); prenatal care (gestational age at first prenatal visit, and number of visits); gestational complications (gestational diabetes and hypertension) and use of substances like tobacco and alcohol. Statistically significant variables (defined as $\mathrm{p}<0.25$ ) according to the individual analyses were selected for the second stage, in which each variable was tested separately in the model containing the predictive target variable. The variable with the largest contribution, measured by goodness of fit, was added to the model. Next, the model containing the variable 
determined in the previous stage was tested for the remaining variables. This procedure was performed until no more statistically significant contribution to the model was observed, according to goodness of fit and the corresponding $\mathrm{p}>0.05$.

The original study was approved by the institutional review boards at each study center. Data from the questionnaires, the object of this secondary study, were treated according to the confidentiality principle.

\section{Results}

From the initial sample of 5,564 pregnant women followed from run-in until hospital discharge, the study analyzed 4,856 women (87.3\%). 708 women were excluded due to lack of information on use of drugs to induce menstruation and maternal characteristics like age, schooling, and skin color, among others. Table 1 shows the distribution of the principal socio-demographic characteristics of the women included in the study.

Of the pregnant women analyzed, 707 (14.6\%) stated having used some product to induce menstruation, of whom 243 reported the use of herbal teas (34.4\%), 200 reported sex hormones (28.3\%), and 120 misoprostol (17\%) (Table 2).

Sex hormones reported by the women included combinations of estrogens and progestagens present in oral contraceptives, injectable medroxyprogesterone, and the association of normethandrone and methylestradiol. The teas included various plant species, like senna, "marcela", and quinine.

To investigate the association between use of misoprostol, sex hormones, or herbal teas and congenital anomalies, data were analyzed from 4,693 pregnant women, after excluding 163 women due to lack of information on presence or absence of congenital anomalies in the newborn. Table 3 shows a positive association for congenital anomaly with misoprostol, with borderline significance (OR $=2.46$; 95\%CI: 0.986.17 ), and for sex hormones (OR $=2.45$; $95 \% \mathrm{CI}$ : 1.17-5.15). The anomalies occurring in women who used misoprostol were: syndactyly, clubfoot, meningomyelocele, microcephaly, and fingernail defects. No association was observed between teas and the target outcome.

Table 3 shows the results of logistic regression. After adjusting for confounders, the positive associations shown in the crude analysis remained for misoprostol $(\mathrm{OR}=2.64$; $95 \% \mathrm{CI}$ : $1.03-6.75)$ and sex hormones $(\mathrm{OR}=2.24$; $95 \% \mathrm{CI}$ : 1.06-4.74).
Table 1

Socio-demographic characteristics of 4,856 pregnant women studied in six Brazilian State capitals. Brazilian Study on Gestational Diabetes. 1991-1995.

\begin{tabular}{|c|c|c|}
\hline Characteristic & $n$ * & $\%$ \\
\hline \multicolumn{3}{|l|}{ Age (years) } \\
\hline $20-24$ & 1,635 & 33.7 \\
\hline $25-29$ & 1,518 & 31.2 \\
\hline $30-48$ & 1,703 & 35.1 \\
\hline \multicolumn{3}{|l|}{ Schooling (years) } \\
\hline$<8$ & 2,186 & 45.1 \\
\hline 8 to 11 & 2,225 & 45.9 \\
\hline$\geq 12$ & 433 & 8.9 \\
\hline \multicolumn{3}{|l|}{ Skin color } \\
\hline White & 2,132 & 43.9 \\
\hline Non-white & 2,724 & 56.1 \\
\hline \multicolumn{3}{|c|}{ Number of children } \\
\hline 0 & 1,302 & 30.1 \\
\hline 1 & 1,411 & 32.6 \\
\hline$\geq 2$ & 1,613 & 37.3 \\
\hline \multicolumn{3}{|l|}{ Marital status } \\
\hline Married & 4,496 & 92.7 \\
\hline Not married & 354 & 7.3 \\
\hline \multicolumn{3}{|c|}{ Planned pregnancy } \\
\hline Yes & 1,605 & 33.1 \\
\hline No & 3,242 & 66.9 \\
\hline \multicolumn{3}{|l|}{ Study center } \\
\hline Porto Alegre & 1,093 & 22.5 \\
\hline Fortaleza & 1,030 & 21.2 \\
\hline São Paulo & 976 & 20.1 \\
\hline Salvador & 844 & 17.4 \\
\hline Rio de Janeiro & 471 & 9.7 \\
\hline Manaus & 442 & 9.1 \\
\hline
\end{tabular}

* Variation in total number of pregnant women in the categories was due to missing data for the respective variables.

Table 2

Drugs used by pregnant women to induce menstruation. Brazilian Study on Gestational Diabetes. 1991-1995 $(n=4,856)$

\begin{tabular}{lcc}
\hline Drug & $\mathbf{n}$ & $\%$ \\
\hline Herbal teas & 243 & 34.4 \\
Sex hormones & 200 & 28.3 \\
Misoprostol & 120 & 17.0 \\
Others * & 144 & 20.3 \\
Total & 707 & 100.0 \\
\hline
\end{tabular}

* Anti-inflammatory analgesics and drugs whose composition was not identified ("cocktail", "medicine to start menstrual period", and other terms mentioned by subjects). 
Crude and adjusted odds ratio (OR) for congenital anomalies. Brazilian Study on Gestational Diabetes. 1991-1995 ( $\mathrm{n}=4,693$ ).

\begin{tabular}{lcccccc}
\hline Drug & \multicolumn{2}{c}{ Exposed } & \multicolumn{2}{c}{ Unexposed } & \multicolumn{2}{c}{$\begin{array}{c}\text { Crude OR } \\
(95 \% \mathrm{Cl})\end{array}$} \\
& $\%$ & $\mathrm{n} /$ total & $\%$ & $\mathrm{n} /$ total & $\begin{array}{c}\text { Adjusted OR * } \\
(95 \% \mathrm{Cl})\end{array}$ \\
\hline Misoprostol & 4.24 & $5 / 118$ & 1.77 & $81 / 4,575$ & $2.46(0.98-6.17)$ & $2.64(1.03-6.75)$ \\
Sex hormones & 4.14 & $8 / 193$ & 1.73 & $78 / 4,500$ & $2.45(1.17-5.15)$ & $2.24(1.06-4.74)$ \\
Herbal teas & 2.48 & $6 / 242$ & 1.80 & $80 / 4,451$ & $1.39(0.60-3.22)$ & $1.66(0.70-3.89)$ \\
\hline
\end{tabular}

* Adjusted for study center.

\section{Discussion}

According to this cohort of pregnant women treated at prenatal services in six Brazilian State capitals, fetuses exposed to misoprostol show a risk of congenital anomaly 2.74 times greater (95\%CI: 1,06-7,05) than that of unexposed fetuses, as diagnosed at birth. A positive association was also observed between use of sex hormones and congenital anomalies.

An analysis of 4,673 cases of birth defects recorded in Brazil from 1989 to 1998 showed no differences in misoprostol exposure rates between newborns with all types of anomalies $(34 / 4,673)$ as compared to the control group $(23 / 4,980)$, consisting of newborns without anomalies 28 . However, there was a positive association between misoprostol and vascular disruption defects. Brasil et al. 29 showed a positive association between misoprostol and various types of congenital anomalies in very low birth weight newborns, with borderline significance, after adjusting for maternal age and birth weight $(\mathrm{OR}=2.4$; 95\%CI: 1.0-6.2). In the study, the controls also had birth weight $<1,500 \mathrm{~g}$, but without a diagnosis of any congenital anomaly.

In order to avoid potential biases due to selection of healthy controls, Vargas et al. 30 compared 93 newborns with various vascular disruption anomalies and 279 controls with minor or chromosomal anomalies, among other birth defects not caused by vascular disruption. Prenatal exposure to misoprostol was identified in 32 cases $(34.4 \%)$ and 12 controls $(4.3 \%)(\mathrm{OR}=11.67$; 95\%CI: 5.68-23.97).

In the current study, the observed birth defects associated with misoprostol were classified as anomalies of the: nervous system (meningomyelocele and microcephaly), musculoskeletal system (clubfoot and syndactyly), and tegument (fingernail defects). These anomalies may be related to vascular disruption, resulting from damage to or interruption of normal vascular devel- opment in the embryo and fetus, according to the mechanism proposed by Bavinck \& Weaver 31 . Importantly, meningomyelocele is a defect that occurs in the fifth week after the date of the last menstrual period, normally when the woman still does not know she is pregnant. Thus, one cannot rule out the hypothesis that the anomaly occurred before the patient took misoprostol.

The principal hormones associated with congenital anomalies were the combination of normethandrone and methylestradiol and compound hormonal contraceptives with levonorgestrel and ethynylestradiol. At the time in which the data were collected, the normethandrone/ methylestradiol combination and medroxyprogesterone acetate were widely used in Brazil as a pregnancy test or in attempts to induce abortion 32 . The following anomalies were associated with the use of hormones in the current analysis: polydactyly, with or without syndactyly (3 cases), syndactyly (1), congenital scoliosis (1), right choanal atresia (1), ambiguous genitalia (1), and hypertrophy of labia minora (1). Although various publications from the 1970s associated the intragestational use of sex hormones with birth defects, meta-analyses of cohort and case-control studies showed that estrogen/progestagen combinations were not associated with increased risk of congenital anomalies in general 33 or genitourinary malformations in particular 34 .

The cases of pseudo-hermaphroditism and masculinization of the genitalia observed in this analysis may be explained by the use of high doses of products containing sex hormones, not as a contraceptive method or pregnancy test, but to attempt to interrupt pregnancy. Literature reviews suggest that the degree of masculinization or abnormal sexual differentiation is dosedependent 34,35 , so that there is no evidence of teratogenic risk associated with inadvertent use of low-dose sex hormones during pregnancy 36 .

Despite some case reports on the toxicity of the medicinal plants reported by women in the 
current study to induce menstruation, no association was observed between the use of herbal teas and congenital anomalies. The wide variety of teas reported by the women, including some products whose composition was impossible to verify, and the relatively small number of congenital anomalies, preclude any conclusion on potential teratogenic effects of the medicinal plants used in this study sample.

The current study presents some limitations. The analysis is based on secondary data, which explains the absence of some useful information like the period of gestation in which misoprostol was used and the combined use of non-pharmacological abortive methods, which would have allowed a more detailed evaluation of the teratogenic risk. In relation to the outcome measures, diagnosis of congenital anomalies was performed by the attending neonatal physician, without confirmation by the researchers involved in the current study. Möebius sequence, for example, can go unnoticed in the initial neonatal evaluation, as can some central nervous system defects, which tend to manifest later (at days or months of life). Therefore, the real association between the products used to induce menstruation and the congenital anomalies may be underestimated in this analysis.
The available data in the literature on the perinatal effects of misoprostol are mostly from cases reports, followed by case-control studies with small samples and major inter-study methodological differences, as shown by a systematic review ${ }^{13}$. In addition, the report of exposure to misoprostol before the outcome (childbirth or intrauterine death) makes the present analysis more reliable than data from case-control studies, in which the use of misoprostol was recorded postpartum.

The question on the use of misoprostol, hormones, and other abortive products during pregnancy involves highly complex problems, like non-medical abortion, irrational drug use, and the importance of congenital anomalies as a proportionally increasing cause of infant mortality 37 . In this context, the association between the use of misoprostol or sex hormones and congenital anomalies as observed in the current study contributes to knowledge on the teratogenic potential of these products used by women to induce menstruation, but with abortion as the probable intent. Meanwhile, the wide variety of teas reported by pregnant women (forming a broad, heterogeneous group) precludes any conclusion on an association between herbal teas and adverse events in the pregnancy outcome in this sample. 


\section{Resumo}

Este estudo avalia a associação do uso do misoprostol e de outros produtos utilizados para induzir a menstruação com anomalia congênita. Foram arroladas consecutivamente 4.856 mulheres com vinte anos de idade ou mais, procedentes de serviços de pré-natal do Sistema Único de Saúde em seis capitais brasileiras. Dados sócio-demográficos e o uso de medicamentos foram obtidos por meio de entrevista, entre a 21a e a 28 a semanas de gestação. Outros dados, incluindo informações sobre o parto e o diagnóstico de anomalia congênita, realizado pelo médico que assistiu o recém-nascido, foram obtidos no prontuário. Potenciais confundidores foram ajustados por meio de regressão logística. O uso de produtos para induzir a menstruação foi relatado por 707 gestantes (14,6\%), das quais 120 (17\%) referiram-se ao misoprostol. Após ajustamento para o centro de realização da pesquisa, foi verificada uma associação positiva entre misoprostol e anomalias congênitas ( $R C=2,64$; IC95\%: 1,03-6,75); para hormônios sexuais também foi verificada uma associação positiva (RC=2,24; IC95\%: 1,06-4,74). Os resultados sugerem que o uso de misoprostol ou hormônios sexuais durante a gravidez aumenta o risco de anomalia congênita.

Misoprostol; Hormônios; Anormalidades; Saúde da Mulher

\section{References}

1. Golderg AB, Greenberg BS, Darney PD. Misoprostol and pregnancy. N Engl J Med 2001; 344:38-46.

2. Song J. Use of misoprostol in obstetrics and gynecology. Obstet Gynecol Surv 2000; 55:503-10.

3. Costa SH. Commercial availability of misoprostol and induced abortion in Brazil. Int J Gynaecol Obstet 1998; 63 Suppl 1:S131-9.

4. Costa SH, Vessey MP. Misoprostol and illegal abortion in Rio de Janeiro, Brazil. Lancet 1993; 341:1258-61.

5. Coêlho HLL, Teixeira AC, Santos AP, Forte EB, Morais SM, La Vecchia C, et al. Misoprostol and illegal abortion in Fortaleza, Brazil. Lancet 1993; 341:1261-3

6. Misago C, Fonseca W, Correia L, Fernandes LM, Campbell O. Determinants of abortion among women admitted to hospitals in Fortaleza, North Eastern Brazil. Int J Epidemiol 1998; 27:833-9.

\section{Contributors}

T. S. Dal-Pizzol participated in the literature review, data cleaning, creation of variables, statistical analysis, and drafting of the article. S. S. Mengue participated in the planning and implementation of the Brazilian Study on Gestational Diabetes, data cleaning, creation of variables, statistical analysis, and drafting of the article. M. T. V. Sanseverino participated in the revision of the article.
7. Mengue SS, Schenkel EP, Duncan BB, Schmidt MI. Prevalence and clinical correlates of unsuccessful use of drugs to induce menstruation. Contraception 1998; 57:93-7.

8. Kulier R, Gülmezoglu AM, Hofmeyr GJ, Cheng LN, Campana A. Medical methods for first trimester abortion. (Cochrane Review). In: The Cochrane Library, Issue 2, 2005. Oxford: Update Software.

9. Norman JE, Thong KJ, Baird DT. Uterine contractility and induction of abortion in early pregnancy by misoprostol and mifepristone. Lancet 1991; 338:1233-6.

10. Gonzalez CH, Marques-Dias MJ, Kim CA, Sugayama SM, Da Paz JA, Huson SM, et al. Congenital abnormalities in Brazilian children associated with misoprostol misuse in first trimester of pregnancy. Lancet 1998; 351:1624-7. 
11. Pastuszak AL, Shüler L, Speck-Martins CE. Use of misoprostol during pregnancy and Möbius' syndrome in infants. N Engl J Med 1998; 338:1881-5.

12. Gonzalez CH, Vargas FR, Perez AB, Kim CA, Brunoni D, Marques-Dias MJ, et al. Limb deficiency with or without Möbius sequence in seven Brazilian children associated with misoprostol use in first trimester of pregnancy. Am J Med Genet 1993; 47:59-64.

13. Dal-Pizzol TS, Knop FP, Mengue SS. Prenatal exposure to misoprostol and congenital anomalies: systematic review and meta-analysis. Reprod Toxicol 2006; 22:666-71.

14. Dal-Pizzol TS, Tierling VL, Schüler-Faccini L, Sanseverino MTV, Mengue SS. Reproductive results associated with misoprostol and other substances utilized for interruption of pregnancy. Eur J Clin Pharmacol 2005; 61:71-2.

15. Organização Mundial da Saúde. Manual da classificação estatística internacional de doenças, lesões e causas de óbitos - nona conferência de revisão. São Paulo: Centro Brasileiro de Classificação de Doenças em Português; 1985.

16. Jornal Brasileiro de Medicina. Dicionário de especialidades farmacêuticas. Rio de Janeiro: Editora de Publicações Médicas; 1984.

17. Jornal Brasileiro de Medicina. Dicionário de especialidades farmacêuticas. Rio de Janeiro: Editora de Publicações Médicas; 1985.

18. Jornal Brasileiro de Medicina. Dicionário de especialidades farmacêuticas. 15a Ed. Rio de Janeiro: Editora de Publicações Médicas; 1986.

19. Jornal Brasileiro de Medicina. Dicionário de especialidades farmacêuticas. 16a Ed. Rio de Janeiro: Editora de Publicações Médicas; 1987.

20. Jornal Brasileiro de Medicina. Dicionário de especialidades farmacêuticas. 17a Ed. Rio de Janeiro: Editora de Publicações Médicas; 1988.

21. Jornal Brasileiro de Medicina. Dicionário de especialidades farmacêuticas. 18a Ed. Rio de Janeiro: Editora de Publicações Médicas; 1989.

22. Jornal Brasileiro de Medicina. Dicionário de especialidades farmacêuticas 19a Ed. Rio de Janeiro: Editora de Publicações Médicas; 1990.

23. Jornal Brasileiro de Medicina. Dicionário de especialidades farmacêuticas. 20a Ed. Rio de Janeiro: Editora de Publicações Médicas; 1991.

24. Jornal Brasileiro de Medicina. Dicionário de especialidades farmacêuticas. 21a Ed. Rio de Janeiro: Editora de Publicações Médicas; 1992.
25. Jornal Brasileiro de Medicina. Dicionário de especialidades farmacêuticas. 22a Ed. Rio de Janeiro: Editora de Publicações Médicas; 1993.

26. Jornal Brasileiro de Medicina. Dicionário de especialidades farmacêuticas. 23a Ed. Rio de Janeiro: Editora de Publicações Médicas; 1994.

27. Jornal Brasileiro de Medicina. Dicionário de especialidades farmacêuticas. 24a Ed. Rio de Janeiro: Editora de Publicações Médicas; 1995.

28. Orioli IM, Castilla EE. Epidemiological assessment of misoprostol teratogenicity. Br J Obstet Gynaecol 2000; 107:519-23.

29. Brasil R, Coêlho HLL, D'Avanzo B, La Vecchia C. Misoprostol and congenital anomalies. Pharmacoepidemiol Drug Saf 2000; 9:401-3.

30. Vargas FR, Schuler-Faccini L, Brunoni D, Kim C, Meloni VF, Sugayama SM, et al. Prenatal exposure to misoprostol and vascular disruption defects: a case-control study. Am J Med Genet 2000; 95: 302-6.

31. Bavinck JN, Weaver DD. Subclavian artery supply disruption sequence: hypothesis of a vascular etiology for Poland, Klippel-Feil, and Möbius anomalies. Am J Med Genet 1986; 23:903-18.

32. Mercucci VL, Bonfim JRA. Casos de desinformação farmacêutica: drogas EP de alta dosagem, acetato de medroxiprogesterona e misoprostol. In: Wolffers I, Hardon A, Janssen J, organizadores. O marketing da fertilidade. São Paulo: Editora Hucitec; 1991. p. 113-38.

33. Bracken MB. Oral contraception and congenital malformation in offspring: a review and metaanalysis of the prospective studies. Obstet Gynecol 1990; 76:552-7.

34. Raman-Wilms T, Tseng AL, Wighardt S, Einarson TR, Koren G. Fetal genital effects of first-trimester sex hormone exposure: a meta-analysis. Obstet Gynecol 1995; 85:141-9.

35. Schardein JL. Congenital abnormalities and hormones during pregnancy: a clinical review. Teratology 1980; 22:251-70.

36. Friedrich C, Troviscal LP, Missaglia V. Hormônios. In: Sanseverino MTV, Spritzer DT, Schüler L, organizadores. Manual de teratogênese. Porto Alegre: Editora da Universidade Federal do Rio Grande do Sul; 2001. p. 199-206.

37. Rosano A, Botto LD, Botting B, Mastroiacovo P. Infant mortality and congenital anomalies from 1950 to 1994: an international perspective. J Epidemiol Community Health 2000; 54:660-6.

\footnotetext{
Submitted on 13/Jun/2007

Final version resubmitted on $06 / \mathrm{Sep} / 2007$

Approved on 25/Oct/2007
} 